\title{
Arsenic carcinogenesis in the skin
}

\author{
Hsin-Su Yu ${ }^{1, *}$, Wei-Ting Liao $^{2}$ \& Chee-Yin Chai ${ }^{3}$ \\ ${ }^{1}$ Department of Dermatology, National Taiwan University Hospital and National Taiwan University College \\ of Medicine, Taipei, Taiwan; ${ }^{2}$ Division of Environmental Health and Occupational Medicine, National Health \\ Research Institutes, Zhunan, Miaoli, Taiwan; ${ }^{3}$ Department of Pathology, Kaohsiung Medical University, \\ Kaohsiung, Taiwan
}

Received 18 April 2006; accepted 9 May 2006

(c) 2006 National Science Council, Taipei

Key words: Arsenic, Bowen's disease, skin cancer, pathomechanism

\section{Summary}

Chronic arsenic poisoning is a world public health issue. Long-term exposure to inorganic arsenic (As) from drinking water has been documented to induce cancers in lung, urinary bladder, kidney, liver and skin in a dose-response relationship. Oxidative stress, chromosomal abnormality and altered growth factors are possible modes of action in arsenic carcinogenesis. Arsenic tends to accumulate in the skin. Skin hyperpigmentation and hyperkeratosis have long been known to be the hallmark signs of chronic As exposure. There are significant associations between these dermatological lesions and risk of skin cancer. The most common arsenic-induced skin cancers are Bowen's disease (carcinoma in situ), basal cell carcinoma (BCC) and squamous cell carcinoma (SCC). Arsenic-induced Bowen's disease (As-BD) is able to transform into invasive BCC and SCC. Individuals with As-BD are considered for more aggressive cancer screening in the lung and urinary bladder. As-BD provides an excellent model for studying the early stages of chemical carcinogenesis in human beings. Arsenic exposure is associated with $\mathrm{G} 2 / \mathrm{M}$ cell cycle arrest and DNA aneuploidy in both cultured keratinocytes and As-BD lesions. These cellular abnormalities relate to the p53 dysfunction induced by arsenic. The characteristic clinical figures of arsenic-induced skin cancer are: (i) occurrence on sun-protected areas of the body; (ii) multiple and recrudescent lesions. Both As and UVB are able to induce skin cancer. Arsenic treatment enhances the cytotoxicity, mutagenicity and clastogenicity of UV in mammalian cells. Both As and UVB induce apoptosis in keratinocytes by caspase- 9 and caspase- 8 signaling, respectively. Combined UVB and As treatments resulted in the antiproliferative and proapoptotic effects by stimulating both caspase pathways in the keratinocytes. UVB irradiation inhibited mutant p53 and ki-67 expression, as well as increased in the number of apoptotic cells in As-BD lesions which resulted in an inhibitory effect on proliferation. AsUVB interaction provides a reasonable explanation for the rare occurrences of arsenical cancer in the sun-exposed skin. The multiple and recurrent skin lesions are associated with cellular immune dysfunction in chronic arsenism. A decrease in peripheral CD4 + cells was noticed in the inhabitants of arsenic exposure areas. There was a decrease in the number of Langerhans cells in As-BD lesion which results in an impaired immune function on the lesional sites. Since CD4 + cells are the target cell affected by As, the interaction between $\mathrm{CD} 4+$ cells and epidermal keratinocytes under As affection might be closely linked to the pathogenesis of multiple occurrence of arsenic-induced skin cancer. In this

\footnotetext{
* To whom correspondence should be addressed. Fax: + 886-2-

23934177, E-mail: dermyu@ ha.mc.ntu.edu.tw
} 
review, we provide and discuss the pathomechanisms of arsenic skin cancer and the relationship to its characteristic figures. Such information is critical for understanding the molecular mechanism for arsenic carcinogenesis in other internal organs.

\section{Introduction}

Arsenic (As) is one of the most toxic metals (metalloids) derived from the natural environment. Arsenic occurs in two oxidative states: a trivalent form, arsenite (As III), and a pentavalent form, arsenate (As V). As III is $2-10$ times more toxic than As V [1]. Organic As is non-toxic whereas inorganic As is toxic. Over the centuries, As has been used for a variety of purposes [2]. Arsenic has been used as a drug or poison for nearly 4,000 years. Inorganic As has been used for the treatment of syphilis, psoriasis and leukemia. Arsenic trioxide is now widely used to induce remission in patients with acute promyelocytic leukemia. In industry, As is used to manufacture paints, fungicides, pesticides, insecticides, herbicides etc. Gallium arsenide and aluminum gallium arsenide crystals are components of semiconductors, high emitting diodes, lasers and variety transistors. Because of the natural distribution of As in the rust of the earth, drinking water is the most common resource of As exposure for the general population [3, 4]. The World Health Organization suggests that maximum permissible limit of groundwater As concentration is $50 \mu \mathrm{g} / 1[5,6]$. Currently, the drinking water As standard in Taiwan, Japan, and U.S. is $10 \mu \mathrm{g} / 1$. In human beings, the adult's acute As poisoning dosage is $0.17-0.87 \mathrm{mg} / \mathrm{kg}$. This acute As exposure dosage causes conditions ranging from diarrhea, vomiting, liver and kidney toxicity [5-7]. Long-term exposure to low dosage of As may induce serious adverse health effects in multiple organs. Chronic health effects of As exposure via drinking water include skin and internal cancers, peripheral vascular disease, ischemic heart disease, cerebral infarction, diabetes mellitus and hypertension. Skin, lung, bladder, kidney, liver and uterus are considered as the sites related to arsenic-induced malignancies $[2,8]$. The skin is thought to be perhaps the most sensitive site. Arsenic-induced skin cancers are usually occur on the sun-protected areas with multiple and recrudescent lesions [9-11]. This review discusses the pathomechanisms of arsenic skin cancer and the relationship to its characteristic figures.

\section{Mechanisms of arsenic carcinogenesis}

The International Agency for Research on Cancer (IARC) has classified As as a human carcinogen [12]. Exposure to As in drinking water is almost exclusive to inorganic As. Various hypotheses have been proposed to explain the carcinogenicity of inorganic arsenic. Oxidative stress, chromosomal abnormality and altered growth factors are possible modes of action in arsenic carcinogenesis $[13,14]$. The mode-of-action studies suggest that the arsenic might be acting as a cocarcinogen, a promoter or a progressor of carcinogensis [15].

\section{Reactive oxygen species}

In human beings, As can be metabolized by s-adenosylmethionine dependent methylation. Arsenic methylation has been generally considered a detoxification process, because the methylated compounds are less genotoxic [16] and are excreted more rapidly in urine than inorganic forms [17]. After ingestion, inorganic As is taken up by red blood cells and then distributed primarily to the liver, kidney, spleen, lung, intestine and skin [18, 19]. As V is reduced to As III in blood. Arsenic is metabolized in the liver to various methylated forms. Enzymatic transfer to arsenite produces monomethylarsenic acid (MMA V), which is reduced to monomethyl arsonous acid (MMA III). A second methylation reaction methylates MMA III to dimethylarsinic acid (DMA V). Some DMA V can then be reduced to DMA III [20]. In this methylation process, reactive oxygen species (ROS) including peroxyl radical, superoxide radical, and hydroxyl radical could be generated [21, 22]. Arsenic is a strong ligand to the thio-group (-SH) of proteins [23]. Arsenic can react with -SH of the reduced glutathione (GSH). Since GSH is one of the most important free radical scavengers, the effects of As on GSH activity will affect cellular abilities of oxidative stress elimination. Directly or indirectly, arsenic-induced oxidative stress can induce further damages in cells, and these oxidative injuries are reported to associate 
with arsenical carcinogenesis. Both in mouse and human skins, arsenic can induce oxidative damage in cellular DNA and generate 8-hydroxyl2 -deoxylguanosine (8-OHdG) oxidative DNA adducts [24-26]. Clinical studies in arsenic-induced Bowen's disease (As-BD) indicate that the increased $8-\mathrm{OHdG}$ levels are positively correlated to the lesional arsenic concentration [26], suggesting the involvement of oxidative stress in arsenical skin carcinogenesis. In vitro studies indicated that ROS induced by low concentrations of arsenic $(<5 \mu \mathrm{M})$ can increase the transcription of the activator protein-1 (AP-1) and the nuclear factor kappa B (NF- $\kappa \mathrm{B})$ [27-30], which results in subsequent stimulation of cell proliferation [31, 32].

\section{Genotoxicity}

Arsenic is known to induce genetic toxicity in mammalian cells. Arsenic is reported to increase the rate of chromosome aberration and sister chromatid exchange that associated with arsenical carcinogenesis [33, 34]. Chromosome aberrations and endoreduplication were induced by arsenite in human fibroblasts and Chinese hamster ovary cells at higher concentrations, in contrast, arsenic induced sister chromatid exchanges at lower concentrations $[35,36]$. These chromosomal abnormalities are reported closely relate to arsenic-induced oxidative DNA damage [26, 37]. Arsenite exposure induces micronuclei (MN) formation in human fibroblasts [38]. Low dose exposure to arsenite results mainly in kinetochore-positive $\left(\mathrm{K}^{+}\right) \mathrm{MN}$ (MN contain centromere), whereas high dose treatment causes $\mathrm{K}$-negative $\mathrm{MN}$ (MN without centromere). $\mathrm{K}^{+} \mathrm{MN}$ are usually derived from whole chromosome and are induced by agents that cause aneuploidy, whereas $\mathrm{X}$-rays and other clastogens induce $\left(\mathrm{K}^{-}\right) \mathrm{MN}[39$, 40]. Therefore at low dose, arsenite acts as an aneugen, but at high dose it acts as a clastogen [15]. An increased frequency of $\mathrm{MN}$ has been detected in exfoliated bladder cells, buccal cells, sputum cells and lymphocytes from arsenic-exposed population [41-43]. Chien et al. reported that arsenite induced an increased frequency of $\mathrm{MN}$ in $\mathrm{HaCaT}$ cells which was associated with tumorigenicity in nude mice [44].

\section{Altered DNA repair}

Arsenic is able to inhibit DNA repair systems [45, 46]. The incision step and the ligation step of nucleotide excision repair were inhibited by arsenite [47]. Arsenite has been reported to decrease the DNA ligase III activity which results in DNA base excision repair [48, 49] and DNA strand break rejoining [50]. Arsenic is also reported to inhibit other DNA repair regulatory proteins including DNA ligase I, DNA ligase II, DNA ligase III, DNA polymerase $\beta, \mathrm{O}^{6}$-methyl-guanineDNA methyltransferase and poly (ADP-ribose) polymerase (PARP) [13, 49, 51]. Interfering of these DNA repair proteins by arsenic is shown to affect genome stabilities of the cells. Arsenite enhances the mutagenicity of carcinogeneic stresses (such as UV, X-rays, and chemical agent) in mammalian cells [52-55]. It is proposed that spontaneous or induced mutations in key genetic sites can then lead to subsequent mutation via inhibited DNA repair by arsenic.

\section{Altered transcription factors}

Arsenic is a strong ligand to the - $\mathrm{SH}$, an important active residue for some regulatory proteins. It is known that about 200 proteins could be affected by arsenic-thio interaction [56]. Among these proteins, the proto-oncogene c-Jun is well-studied. Arsenic can block Jun N-terminal kinase (JNK) phosphatase activity via binding with its -SH. Since JNK phosphatase functions as a negative regulator of JNK, arsenic-induced JNK phosphatase dysfunction will cause irreversible activation of JNK. This JNK activation can further activate proto-oncogene c-Jun and the subsequent gene expression regulated by cJun/c-Fos complex (AP-1) [30, 57]. The effects of arsenic on transcription factor AP-1, as well as $\mathrm{NF}-\kappa \mathrm{B}$, can induce series of abnormalities in cell functions. In which, the abnormalities in growth factor expression, cell cycle regulation, and apoptotic signaling are most closely associated with arsenic carcinogenesis. It is reported that long-term low dose arsenic exposure can enhance cellular sensitivity and response to epithelial growth factor (EGF) [31, 58] which can further inhibit cell cycle inhibitory protein p27 expression and cause cell hyperproliferation via c-myc 
and E2F-1 regulatory pathway [59]. Arsenic can also enhance keratinocytes to express $\mathrm{TGF}-\alpha$, GM-CSF, IL-6 and IL-8 [31, 58, 60]. These arsenic-induced growth factors and cytokines expression are reported to associate with arsenic-induced cutaneous tumorigenesis via AP-1 and $\mathrm{NF}-\kappa \mathrm{B}$ regulation [61]. High concentrations of arsenic can induce significant cellular and DNA injuries. Arsenic-induced DNA damages are reported to activate p53-associated cell cycle checking and result in $\mathrm{G} 2 / \mathrm{M}$ cell cycle arrest. Since arsenic exposure can inhibit DNA repair system, this p53-associated cell cycle checking will possibly fail and p53-regulated apoptotic cell death will be activated [62-65].

\section{Arsenic and skin cancer}

Arsenic tends to concentrate in ectodermal tissue including the skin, hair and nail. Thus, skin lesions (both malignant and non-malignant lesions) are considered to be the most common adverse health effects associated with chronic arsenic exposure in humans [66-68]. Skin hyperpigmentation and hyperkeratosis have long been known to be the hallmark signs of chronic arsenic exposure. They were the most common health effects found in populations exposed to arsenic-contaminated drinking water in many countries including Taiwan [9], Chile [69], Argentina [70], India [71, 72] and Bangladesh [73]. Hyperpigmentation occurs as diffuse brownish black pigmentation with a characteristic "rain drop" hypopigmentation. The hyperkeratosis may appear as a uniform thickening or as discrete nodules. It is emphasized that both palmar and plantar keratosis are a significant diagnostic criterion [71, 74]. There was a significant association between the concentration of arsenic in well water and the prevalence of hyperpigmentation and hyperkeratosis among the residents living in the arsenic-exposed areas [9, 71]. Both arsenicinduced skin lesions may be considered as a longterm biomarker of arsenic exposure [8]. There were significant associations between these dermatological lesions and risk of skin cancers. Tseng et al revealed a dose-response relationship between arsenic levels in drinking water and skin cancers. The most common arsenic-induced skin cancers are Bowen's disease, basal cell carcinoma and squamous cell carcinoma [9].
Bowen's disease is a carcinoma in situ of the skin, precancerous in nature, and has been well documented as a consequence of arsenical exposure [911, 66]. Clinically, Arsenic-induced Bowen's disease can be distinguished from non-arsenical Bowen's disease by its occurrence loci on sun-protected areas of the body and its multiple and recrudescent lesions $[9,11,75]$. Abnormal cellular proliferation and dysplasia are observed in the epidermal lesion of BD with significant apoptotic and dyskeratotic keratinocytes[11, 66]. Most of non-arsenical BD showed complete remission after surgical operation, however, many of As-BD may recur after surgery. Furthermore, As-BD lesion is able to transform into invasive SCC, BCC and combined forms of the skin cancer $[9,11,76,77]$. Arsenic-induced cancers of other internal organs are reported to associate with As-BD lesions $[10,11,76]$. Individuals with documented As-BD are considered for more aggressive screening for long-term complications, especially the development of malignancies in the lung and urinary bladder [77-80]. It was indicated that As-BD started within 10 years, invasive skin cancer after 20-30 years [81], and pulmonary cancer after 30 years following the suspected arsenic exposure [76]. Therefore, the characteristic pathological and clinical features of As-BD may provide evidences of arsenic-induced cellular responses in the early stages of chemical carcinogenesis.

\section{Pathomechanisms of arsenic-induced Bowen's disease}

In vitro investigations had identified that arsenic could induce p53 accumulation through an ATM-dependent pathway [65, 82]. Histopathological studies indicated that $\mathrm{p} 53$ protein was highly expressed in As-BD as compared with non-arsenical BD [83, 84]. The over-expressed p53 in As-BD lesions was a mutant form [85, 86]. Most of the p53 mutation sites are located on exon 5 and exon 8 . Furthermore, the mutation types of p53 gene mutation in arsenic-associated skin cancers are different from those in UV-induced skin cancers [87]. Chromosomal instability and aneuploidy were also commonly observed in As-BD lesions [88]. These findings suggest that dysplasia in As-BD is associated with p53 mutation. However, other study did not find significant association between p53 mutation and As-BD [86]. Although the linkage between p53 mutation and arsenic exposure is not 
clear, the affect of arsenic on p53 regulation is well documented. Both in vitro and As-BD lesion studies indicated that arsenic exposure was associated with G2/M cell cycle arrest and DNA aneuploidy [88-90]. These cellular abnormalities may associate with p53 dysfunction induced by arsenic.

Hyperproliferative and dyskeratotic (apoptotic) keratinocytes co-existed in As-BD lesions. In vitro study indicated that the co-existence of hyperpoliferative and dyskeratotic keratinocytes might relate to the biological effects of arsenic on human keratinocytes [91]. The effects of As on keratinocytes depend on the concentrations of arsenic. At lower concentrations $(\leq 1 \mu \mathrm{M})$, arsenic induced keratinocyte proliferation and enhanced both NF- $\kappa \mathrm{B}$ and AP-1 activity [91]. Keratinocyte apoptosis was not induced at low arsenic concentration $(1 \mu \mathrm{M})$, which may relate to the anti-apoptotis signals of NF- $\kappa \mathrm{B}$ [92] or the apoptosis resistant nature of keratinocytes. At higher concentrations $(\geq 5 \mu \mathrm{M})$, arsenic induced keratinocyte apoptosis by Fas/Fas ligand (FasL) pathway. At apoptosis inducing concentrations, $\mathrm{NF}-\kappa \mathrm{B}$ activity was not enhanced, however, AP-1 activity was further enhanced [91]. Since promoter regions of FasL contain binding sites for AP-1, arsenic-activated Fas/FasL signaling may associate with arsenic-induced AP-1 activation [93-95].

\section{Effects of UVB on arsenic-induced skin cancer}

Clinically, As-induced skin cancer lesions are usually on sun-protected skin. UVB has been used to treating many hyperproliferative dermatoses including psoriasis and cutaneous T-cell lymphoma. UVB may play a modulatory role in the skin arsenic carcinogenesis. Chai et al revealed that UVB irradiation reduces mutant p53 and ki-67 expression, as well as decreases in the number of apoptotic cells in As-BD lesions [85] which results in an inhibitory effect on cell proliferation (Figure 1).

Arsenic is not mutagenic in bacterial or mammalian cells, but it reinforces mutations induced by various mutagens including UVB. Reports investigating the interaction of UVB and arsenic have focused on the DNA excision repair and replication. Inhibition of pyrimidine dimers excision [96] and postreplication repair [45, 48] by arsenic is responsible for the cytotoxicity and mutagenesis of UV in Chinese hamster ovary cells.
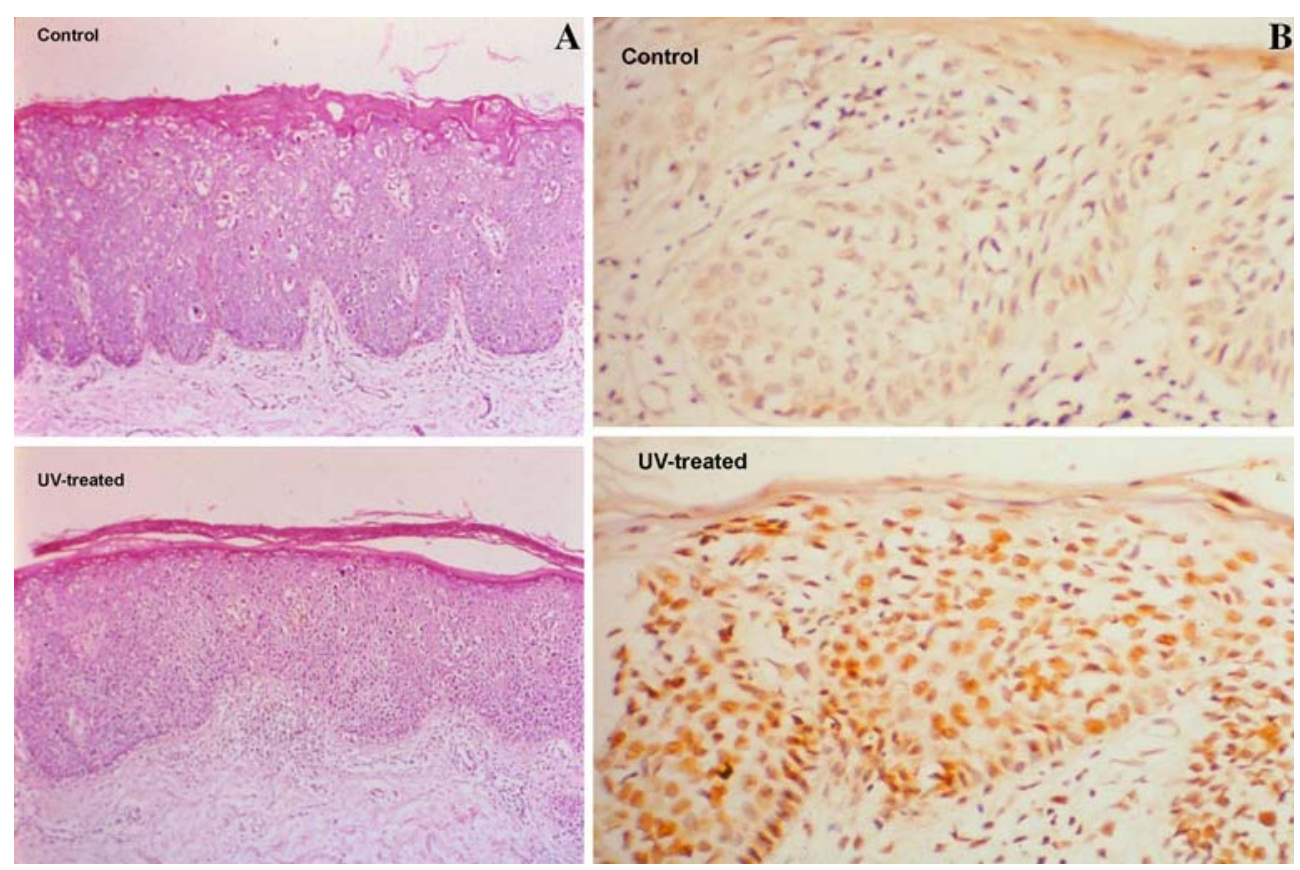

Figure 1. UVB irradiation on As-BD lesions. (a) HE staining of As-BD lesion from a patient before and after UVB irradation $\left(75 \mathrm{~mJ} / \mathrm{cm}^{2} \times 5\right.$ times $/ \mathrm{wk} \times 2=750 \mathrm{~mJ} / \mathrm{cm}^{2}$ UVB total). UVB irradiation showed significant effects on decreasing dysplasia and dyskeratotic cells of the lesion. (b) TUNEL staining of apoptotic cells after UVB irradiation. UVB irradiation induced apoptosis in lesional kerationcytes. 
Arsenic treatment enhances the cytotoxicity, mutagenicity, and clastogenicity of UV light in Chinese hamster ovary cells [97]. UV-induced DNA damage leads to p53-mediated apoptosis [98, 99]. Upon severe DNA damage, p53 upregulates Bax that binds to the mitochondria membrane and activates caspase- 9 and caspase-3, leading to downstream apoptotic responses [100, 101]. Arsenic causes apoptosis of human keratinocytes through the Fas/FasL pathway with enhanced AP-1 activity. Downstream signals of Fas/FasL pathway, including FADD, caspase-8, caspase-3 and PARP cleavage, are activated [91]. Therefore, activation of a different primary caspase is involved in apoptosis induced by $A s$ as compared to UVB-induced apoptosis. In vitro study revealed that arsenic enhances UVB-induced keratinocyte apoptosis via suppression of Bcl-2 expression and stimulation of caspase- 8 activity (Figure 2). Combined UVB and arsenic treatment resulted in the antiproliferative and proapoptotic effects in the keratinocytes [75]. As-UVB interaction provides a reasonable explanation for the rare occurrences of arsenical cancer in the sun-exposed skin.

\section{Immunological dysfunction in arsenic-induced skin cancer}

Previous reports indicated that the multiple and recurrent skin lesions are associated with cellular immune dysfunction in patients with chronic arsenism. It was reported that arsenic exposure was associated with the decreased number in $\mathrm{CD} 4+$ cells ( $\mathrm{T}$ helper) both in adults and in children [102, 103]. Furthermore, increased arsenic exposure is associated with decreased proliferative response to mitogen (phytohemagutinin) stimulation in CD4 + cells. Patients with arsenic-induced skin cancer showed increased gene expression of inflammatory molecules, such as IL-1 $\beta$, IL-6, CD14, C-C and C-X-C chemokine motif ligand [104]. Impaired delayed-type hypersensitivity response to 2,4-dinitrochlorobenzene was observed in patients with As-BD. The association of impaired cellular immunity may be attributed to the effects of arsenic on human lymphocytes. The defective cell-mediated immune function in As-BD was related to an impairment of IL-2 receptor expression and a decrease in CD4+ cells after chronic arsenic exposure [102]. The decreased $\mathrm{CD} 4+$ cell number was related to arsenic induced CD4 + cell apoptosis via the TNF-R1 pathway [105]. In addition to these systemic effects in immune cells by arsenic, immune cell alternations in As-BD lesions were also observed in As-BD. There was a progressive decrease in the number of Langerhans cells in the order of normal skin, normal appearing skin in As-BD, and As-BD lesion. The Langerhans cell density in As-BD was not correlated with the perilesional infiltrates.

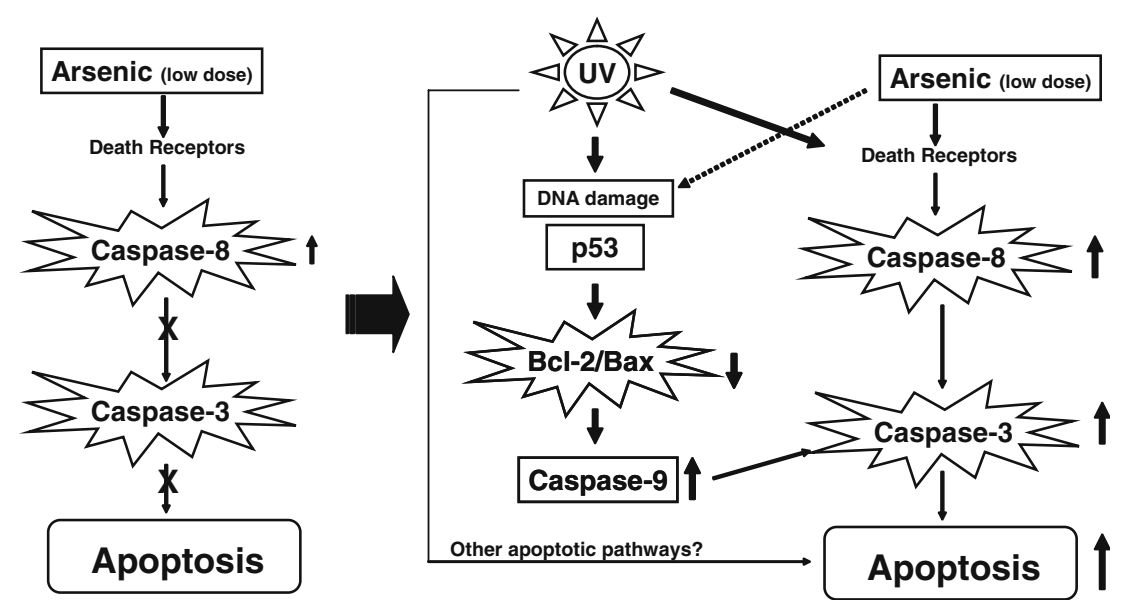

Figure 2. A scheme of arsenic and UVB interaction in keratinocyte apoptosis. Low doses $(\leq 1 \mu \mathrm{M})$ exposure of arsenic enhanced human keratinocytes to express death receptors (including Fas) and its downstream caspase- 8 expression. However, low dosage of arsenic did not activate further caspase cascade and apoptosis in keratinocytes (left). UVB irradiation induces keratinocyte apoptosis majorly via caspase-9 pathway. Combined UVB irradiation, low doses of arsenic further enhanced UVB-induced caspase-9 activation, as well as caspase- 8 activation. In this condition, the downstream effector caspase (caspase-3) was significantly activated and keratinocyte apoptosis was increased. Nontoxic concentrations of arsenic can significantly increase UVB-induced keratinocyte apoptosis via further activating UVB-associated caspase signals (right). 
Most of the infiltrating cells in the peritumoral area of arsenic-induced skin cancer are $\mathrm{T}$ cells [106]. Langerhans cells are known to be one of the antigen presenting cells for $\mathrm{T}$ lymphocytes. They play a pivotal role in the presentation of tumorassociated antigens in neoplastic tissue, thereby facilitating $\mathrm{T}$ cell-mediated antitumoral immune responses [107-109]. The decreased Langerhans cells in As-BD lesions implied an impaired immune function on the lesional epidermis itself. CD4 + cells carrying acquired dendritic cell antigen-presenting machinery can efficiently stimulate cytotoxic T lymphocyte response [110]. Since $\mathrm{CD} 4+$ cell is the target cell affected by arsenic, the interaction between CD4 + cells and epidermal keratinocytes under arsenic affection might be closely linked to the pathogenesis of the multiple and recrudescent arsenic-induced skin cancer.

Epidemiological studies revealed that longterm exposure to arsenic induces cancers in lung, urinary bladder, kidney, liver, uterus and skin. Arsenic skin cancer is usually located on sunprotected areas with multiple and recrudescent lesions. In this review, we provide and discuss the pathomechanisms of arsenic skin cancer and the relationship to its characteristic clinical figures. Such information is critical for clarifying the molecular mechanism for arsenic carcinogenesis in other internal organs.

\section{Acknowledgements}

This study was supported by the National Science Council research grant NSC93-2320-B-002059 and the National Health Research Institute research grant NHRI-EX94-9231SI, Taiwan.

\section{References}

1. Kosnett M.J., Arsenic, In: Olson K.K. (Ed), Poisoning and Drug Overdose. Appleton and Lange, Norwalk, 1994, pp. 87-89.

2. Mead M.N., Arsenic: in search of an antidote to a global poison. Environ Health Perspect 113: A378A386, 2005.

3. Gebel T., Confounding variables in the environmental toxicology of arsenic. Toxicology 144: 155-162, 2000.

4. Chowdhury U.K., Biswas B.K., Chowdhury T.R., Samanta G., Mandal B.K., Basu G.C., Chanda C.R., Lodh D., Saha K.C., Mukherjee S.K., Roy S., Kabir S., Quamruzzaman Q. and Chakraborti D., Groundwater arsenic contamination in Bangladesh and West Bengal, India. Environ Health Perspect 108: 393-397, 2000.

5. IARC, IARC Monograqhs on Evaluation of Carcinogenic Risk of Chemicals to Humans, Vol 23: Some metals and metallic compound: arsenic and arsenic compounds. International Agency for Research on Cancer, LYON, France, 1980.

6. WHO. Environ health criteria: arsenic and arsenic compounds. Vol. 224, 2nd edn. World Health Organization, 2001.

7. WHO. Arsenic, drinking-water and health risk substitution in arsenic mitigation: A discussion paper. World Health Organization, 2003.

8. Chen C.J., Hsu L.I., Wang C.H., Shih W.L., Hsu Y.H., Tseng M.P., Lin Y.C., Chou W.L., Chen C.Y., Lee C.Y., Wang L.H., Cheng Y.C., Chen C.L., Chen S.Y., Wang Y.H., Hsueh Y.M., Chiou H.Y. and Wu M.M., Biomarkers of exposure, effect, and susceptibility of arsenic-induced health hazards in Taiwan. Toxicol Appl Pharmacol 206: 198-206, 2005.

9. Tseng W.P., Chu H.M., How S.W., Fong J.M., Lin C.S. and Yeh S., Prevalence of skin cancer in an endemic area of chronic arsenicism in Taiwan. J Natl Cancer Inst 40: 453-463, 1968.

10. Yeh S., How S.W. and Lin C.S., Arsenical cancer of skin. Histologic study with special reference to Bowen's disease. Cancer 21: 312-339, 1968.

11. Yu H.S., Lee C.H., Jee S.H., Ho C.K. and Guo Y.L., Environmental and occupational skin diseases in Taiwan. J Dermatol 28: 628-631, 2001.

12. IARC, IARC Monographs on the Evaluation of the Carcinogenic Risk of Chemicals to Man-overall Evaluations of Carcinogenicity: An Update of IARC Monograph 1 to 42: Arsenic and Arsenic Compound. IARC, Lyon, France, 1987.

13. Kitchin K.T., Recent advances in arsenic carcinogenesis: modes of action, animal model systems, and methylated arsenic metabolites. Toxicol Appl Pharmacol 172: 249261, 2001.

14. Tchounwou P.B., Patlolla A.K. and Centeno J.A., Carcinogenic and systemic health effects associated with arsenic exposure-a critical review. Toxicol Pathol 31: 575-588, 2003.

15. Rossman T.G., Uddin A.N. and Burns F.J., Evidence that arsenite acts as a cocarcinogen in skin cancer. Toxicol Appl Pharmacol 198: 394-404, 2004.

16. Moore M.M., Harrington-Brock K. and Doerr C.L., Relative genotoxic potency of arsenic and its methylated metabolites. Mutat Res 386: 279-290, 1997.

17. Buchet J.P., Lauwerys R. and Roels H., Urinary excretion of inorganic arsenic and its metabolites after repeated ingestion of sodium metaarsenite by volunteers. Int Arch Occup Environ Health 48: 111-118, 1981.

18. Yamauch H. and Fowler B.A., Toxicity and metabolism of inorganic and methylated arsenicals, In: Nriagu J.Q. (Ed), Arsenic in the Evironment. Part II: Human Health and Ecosystem Effects. John Wiley and Sons, New York, 1994, pp. 35-53.

19. Hsueh Y.M., Huang Y.L., Huang C.C., Wu W.L., Chen H.M., Yang M.H., Lue L.C. and Chen C.J., Urinary levels of inorganic and organic arsenic metabolites among residents in an arseniasis-hyperendemic area in Taiwan. J Toxicol Environ Health A 54: 431444, 1998. 
20. Thomas D.J., Styblo M. and Lin S., The cellular metabolism and systemic toxicity of arsenic. Toxicol Appl Pharmacol 176: 127-144, 2001.

21. Yamanaka K., Hoshino M., Okamoto M., Sawamura R., Hasegawa A. and Okada S., Induction of DNA damage by dimethylarsine, ametabolite of inorganic arsenics, is for the major part likely due to its peroxyl radical. Biochem Biophys Res Commun 168: 58-64, 1990.

22. Mass M.J., Tennant A., Roop B.C., Cullen W.R., Styblo M., Thomas D.J. and Kligerman A.D., Methylated trivalent arsenic species are genotoxic. Chem Res Toxicol 14: 355-361, 2001.

23. Snow E.T., Metal carcinogenesis: mechanistic implications. Pharmacol Ther 53: 31-65, 1992.

24. Wanibuchi H., Hori T., Meenakshi V., Ichihara T., Yamamoto S., Yano Y., Otani S., Nakae D., Konishi Y. and Fukushima S., Promotion of rat hepatocarcinogenesis by dimethylarsinic acid: association with elevated ornithine decarboxylase activity and formation of 8hydroxydeoxyguanosine in the liver. Jpn J Cancer Res 88: 1149-1154, 1997.

25. Yamamoto S., Wanibuchi H., Hori T., Yano Y., Matsui-Yuasa I., Otani S., Chen H., Yoshida K., Kuroda K., Endo G. and Fukushima S., Possible carcinogenic potential of dimethylarsinic acid as assessed in rat in vivo models: a review. Mutat Res 386: 353-361, 1997.

26. Matsui M., Nishigori C., Toyokuni S., Takada J., Akaboshi M., Ishikawa M., Imamura S. and Miyachi Y., The role of oxidative DNA damage in human arsenic carcinogenesis: detection of 8-hydroxy-2'-deoxyguanosine in arsenic-related Bowen's disease. J Invest Dermatol 113: 26-31, 1999

27. Barchowsky A., Dudek E.J., Treadwell M.D. and Wetterhahn K.E., Arsenic induces oxidant stress and NF-kappa B activation in cultured aortic endothelial cells. Free Radic Biol Med 21: 783-790, 1996.

28. Huang C., Li J., Ding M., Wang L., Shi X., Castranova V., Vallyathan V., Ju G. and Costa M., Arsenic-induced NFkappaB transactivation through Erks- and JNKsdependent pathways in mouse epidermal JB6 cells. Mol Cell Biochem 222: 29-34, 2001.

29. Wijeweera J.B., Gandolfi A.J., Parrish A. and Lantz R.C., Sodium arsenite enhances AP-1 and NFkappaB DNA binding and induces stress protein expression in precisioncut rat lung slices. Toxicol Sci 61: 283-294, 2001.

30. Cavigelli M., Li W.W., Lin A., Su B., Yoshioka K. and Karin M., The tumor promoter arsenite stimulates AP-1 activity by inhibiting a JNK phosphatase. Embo J 15: 6269-6279, 1996.

31. Germolec D.R., Yoshida T., Gaido K., Wilmer J.L., Simeonova P.P., Kayama F., Burleson F., Dong W., Lange R.W. and Luster M.I., Arsenic induces overexpression of growth factors in human keratinocytes. Toxicol Appl Pharmacol 141: 308-318, 1996.

32. Dong Z., The molecular mechanisms of arsenic-induced cell transformation and apoptosis. Environ Health Perspect 110(Suppl 5) 757-759, 2002.

33. Lee T.C., Tanaka N., Lamb P.W., Gilmer T.M. and Barrett J.C., Induction of gene amplification by arsenic. Science 241: 79-81, 1988.

34. Mahata J., Basu A., Ghoshal S., Sarkar J.N., Roy A.K., Poddar G., Nandy A.K., Banerjee A., Ray K., Natarajan A.T., Nilsson R. and Giri A.K., Chromosomal aberrations and sister chromatid exchanges in individuals exposed to arsenic through drinking water in West Bengal, India. Mutat Res 534: 133-143, 2003.

35. Huang R.N., Ho I.C., Yih L.H. and Lee T.C., Sodium arsenite induces chromosome endoreduplication and inhibits protein phosphatase activity in human fibroblasts. Environ Mol Mutagen 25: 188-196, 1995.

36. Kochhar T.S., Howard W., Hoffman S. and Brammer-Carleton L., Effect of trivalent and pentavalent arsenic in causing chromosome alterations in cultured Chinese hamster ovary (CHO) cells. Toxicol Lett 84: 3742, 1996.

37. Yamanaka K. and Okada S., Induction of lung-specific DNA damage by metabolically methylated arsenics via the production of free radicals. Environ Health Perspect 102(Suppl 3) 37-40, 1994.

38. Yih L.H. and Lee T.C., Effects of exposure protocols on induction of kinetochore-plus and -minus micronuclei by arsenite in diploid human fibroblasts. Mutat Res 440: 7582, 1999.

39. Eastmond D.A. and Tucker J.D., Kinetochore localization in micronucleated cytokinesis-blocked Chinese hamster ovary cells: a new and rapid assay for identifying aneuploidy-inducing agents. Mutat Res 224: 517-525, 1989.

40. Fenech M., Crott J., Turner J. and Brown S., Necrosis, apoptosis, cytostasis and DNA damage in human lymphocytes measured simultaneously within the cytokinesisblock micronucleus assay: description of the method and results for hydrogen peroxide. Mutagenesis 14: 605-612, 1999.

41. Basu A., Mahata J., Roy A.K., Sarkar J.N., Poddar G., Nandy A.K., Sarkar P.K., Dutta P.K., Banerjee A., Das M., Ray K., Roychaudhury S., Natarajan A.T., Nilsson R. and Giri A.K., Enhanced frequency of micronuclei in individuals exposed to arsenic through drinking water in West Bengal, India. Mutat Res 516: 2940, 2002.

42. Tian D., Ma H., Feng Z., Xia Y., Le X.C., Ni Z., Allen J., Collins B., Schreinemachers D. and Mumford J.L., Analyses of micronuclei in exfoliated epithelial cells from individuals chronically exposed to arsenic via drinking water in inner Mongolia, China. J Toxicol Environ Health A 64: 473-484, 2001.

43. Warner M.L., Moore L.E., Smith M.T., Kalman D.A., Fanning E. and Smith A.H., Increased micronuclei in exfoliated bladder cells of individuals who chronically ingest arsenic-contaminated water in Nevada. Cancer Epidemiol Biomarkers Prev 3: 583-590, 1994.

44. Chien C.W., Chiang M.C., Ho I.C. and Lee T.C., Association of chromosomal alterations with arseniteinduced tumorigenicity of human $\mathrm{HaCaT}$ keratinocytes in nude mice. Environ Health Perspect 112: 1704-1710, 2004.

45. Lee-Chen S.F., Yu C.T. and Jan K.Y., Effect of arsenite on the DNA repair of UV-irradiated Chinese hamster ovary cells. Mutagenesis 7: 51-55, 1992.

46. Hamadeh H.K., Trouba K.J., Amin R.P., Afshari C.A. and Germolec D., Coordination of altered DNA repair and damage pathways in arsenite-exposed keratinocytes. Toxicol Sci 69: 306-316, 2002.

47. Hartwig A., Groblinghoff U.D., Beyersmann D., Natarajan A.T., Filon R. and Mullenders L.H., Interaction of arsenic(III) with nucleotide excision repair in UVirradiated human fibroblasts. Carcinogenesis 18: 399 $405,1989$. 
48. Li J.H. and Rossman T.G., Inhibition of DNA ligase activity by arsenite: a possible mechanism of its comutagenesis. Mol Toxicol 2: 1-9, 1989.

49. Hu Y., Su L. and Snow E.T., Arsenic toxicity is enzyme specific and its affects on ligation are not caused by the direct inhibition of DNA repair enzymes. Mutat Res 408: 203-218, 1998

50. Lynn S., Lai H.T., Gurr J.R. and Jan K.Y., Arsenite retards DNA break rejoining by inhibiting DNA ligation. Mutagenesis 12: 353-358, 1997.

51. Yager J.W. and Wiencke J.K., Inhibition of poly(ADPribose) polymerase by arsenite. Mutat Res 386: 345-351, 1997.

52. Rossman T.G., Mechanism of arsenic carcinogenesis: an integrated approach. Mutat Res 533: 37-65, 2003.

53. Lee T.C., Oshimura M. and Barrett J.C., Comparison of arsenic-induced cell transformation, cytotoxicity, mutation and cytogenetic effects in Syrian hamster embryo cells in culture. Carcinogenesis 6: 1421-1426, 1985.

54. Lee T.C., Lee K.C., Tzeng Y.J., Huang R.Y. and Jan K.Y., Sodium arsenite potentiates the clastogenicity and mutagenicity of DNA crosslinking agents. Environ Mutagen 8: 119-128, 1986

55. Yang J.L., Chen M.F., Wu C.W. and Lee T.C., Posttreatment with sodium arsenite alters the mutational spectrum induced by ultraviolet light irradiation in Chinese hamster ovary cells. Environ Mol Mutagen 20: 156-164, 1992.

56. Abernathy C.O., Liu Y.P., Longfellow D., Aposhian H.V., Beck B., Fowler B., Goyer R., Menzer R., Rossman T., Thompson C. and Waalkes M., Arsenic: health effects, mechanisms of actions, and research issues. Environ Health Perspect 107: 593-597, 1999.

57. Burleson F.G., Simeonova P.P., Germolec D.R. and Luster M.I., Dermatotoxic chemical stimulate of c-jun and c-fos transcription and AP-1 DNA binding in human keratinocytes. Res Commun Mol Pathol Pharmacol 93: 131-148, 1996.

58. Germolec D.R., Spalding J., Yu H.S., Chen G.S., Simeonova P.P., Humble M.C., Bruccoleri A., Boorman G.A., Foley J.F., Yoshida T. and Luster M.I., Arsenic enhancement of skin neoplasia by chronic stimulation of growth factors. Am J Pathol 153: 1775-1785, 1998.

59. Trouba K.J., Wauson E.M. and Vorce R.L., Sodium arsenite-induced dysregulation of proteins involved in proliferative signaling. Toxicol Appl Pharmacol 164: 161170,2000

60. Yen H.T., Chiang L.C., Wen K.H., Chang S.F., Tsai C.C., Yu C.L. and Yu H.S., Arsenic induces interleukin-8 expression in cultured keratinocytes. Arch Dermatol Res 288: 716-717, 1996

61. Vega L., Styblo M., Patterson R., Cullen W., Wang C. and Germolec D., Differential effects of trivalent and pentavalent arsenicals on cell proliferation and cytokine secretion in normal human epidermal keratinocytes. Toxicol Appl Pharmacol 172: 225-232, 2001.

62. Lee T.C., Tzeng S.F., Chang W.J., Lin Y.C. and Jan K.Y., Post-treatments with sodium arsenite during G2 enhance the frequency of chromosomal aberrations induced by S-dependent clastogens. Mutat Res 163: 263-269, 1986.

63. Liu Q., Hilsenbeck S. and Gazitt Y., Arsenic trioxideinduced apoptosis in myeloma cells: p53-dependent G1 or $\mathrm{G} 2 / \mathrm{M}$ cell cycle arrest, activation of caspase- 8 or caspase-9, and synergy with APO2/TRAIL. Blood 101: 4078-4087, 2003.

64. Mei N., Lee J., Sun X., Xing J.Z., Hanson J., Le X.C. and Weinfeld M., Genetic predisposition to the cytotoxicity of arsenic: the role of DNA damage and ATM. Faseb J 17: 2310-2312, 2003.

65. Yih L.H. and Lee T.C., Arsenite induces p53 accumulation through an ATM-dependent pathway in human fibroblasts. Cancer Res 60: 6346-6352, 2000.

66. Centeno J.A., Mullick F.G., Martinez L., Page N.P., Gibb H., Longfellow D., Thompson C. and Ladich E.R., Pathology related to chronic arsenic exposure. Environ Health Perspect 110(Suppl 5) 883-886, 2002.

67. Yeh S., Skin cancer in chronic arsenicism. Hum Pathol 4: 469-485, 1973

68. Alain G., Tousignant J. and Rozenfarb E., Chronic arsenic toxicity. Int J Dermatol 32: 899-901, 1993.

69. Borgono J.M., Vicent P., Venturino H. and Infante A., Arsenic in the drinking water of the city of Antofagasta: epidemiological and clinical study before and after the installation of a treatment plant. Environ Health Perspect 19: 103-105, 1977

70. Zaldivar R., Arsenic contamination of drinking water and foodstuffs causing endemic chronic poisoning. Beitr Pathol 151: 384-400, 1974.

71. Guha Mazumder D.N., Haque R., Ghosh N., De B.K., Santra A., Chakraborty D. and Smith A.H., Arsenic levels in drinking water and the prevalence of skin lesions in West Bengal, India. Int J Epidemiol 27: 871-877, 1998.

72. Mazumder D.N., Das Gupta J., Santra A., Pal A., Ghose A. and Sarkar S., Chronic arsenic toxicity in west Bengal the worst calamity in the world. J Indian Med Assoc 96: 4-7, 18, 1998.

73. Ahsan H., Perrin M., Rahman A., Parvez F., Stute M., Zheng Y., Milton A.H., Brandt-Rauf P., van Geen A. and Graziano J., Associations between drinking water and urinary arsenic levels and skin lesions in Bangladesh. J Occup Environ Med 42: 1195-1201, 2000.

74. Yu H.S., Blackfoot disease and chronic arsenism in southern Taiwan. Int J Dermatol 23: 258-260, 1984.

75. Lee C.H., Yu C.L., Liao W.T., Kao Y.H., Chai C.Y., Chen G.S. and Yu H.S., Effects and interactions of low doses of arsenic and UVB on keratinocyte apoptosis. Chem Res Toxicol 17: 1199-1205, 2004.

76. Miki Y., Kawatsu T., Matsuda K., Machino H. and Kubo $\mathrm{K}$., Cutaneous and pulmonary cancers associated with Bowen's disease. J Am Acad Dermatol 6: 26-31, 1982.

77. Kim H.J., Min H.G. and Lee E.S., Bowen's diseases and basal cell carcinomas in a patient. J Dermatol 26: 695-697, 1999.

78. Koh E., Kondoh N., Kaihara H., Fujioka H. and Kitamura K., Ureteral tumor with multiple Bowen's disease forty-two years after exposure to arsenic. Eur Urol 16: 398-400, 1989.

79. Yu R.C., Hsu K.H., Chen C.J. and Froines J.R., Arsenic methylation capacity and skin cancer. Cancer Epidemiol Biomarkers Prev 9: 1259-1262, 2000.

80. Lee L. and Bebb G., A case of Bowen's disease and smallcell lung carcinoma: long-term consequences of chronic arsenic exposure in Chinese traditional medicine. Environ Health Perspect 113: 207-210, 2005.

81. Yoshida T., Yamauchi H. and Fan Sun G., Chronic health effects in people exposed to arsenic via the drinking 
water: dose-response relationships in review. Toxicol Appl Pharmacol 198: 243-252, 2004.

82. Menendez D., Mora G., Salazar A.M. and OstroskyWegman P., ATM status confers sensitivity to arsenic cytotoxic effects. Mutagenesis 16: 443-448, 2001.

83. Kuo T.T., Hu S., Lo S.K. and Chan H.L., p53 expression and proliferative activity in Bowen's disease with or without chronic arsenic exposure. Hum Pathol 28 : 786-790, 1997.

84. Chang C.H., Tsai R.K., Chen G.S., Yu H.S. and Chai C.Y., Expression of bcl-2, p53 and $\mathrm{Ki}-67$ in arsenical skin cancers. J Cutan Pathol 25: 457-462, 1998.

85. Chai C.Y., Yu H.S., Yen H.T., Tsai K.B., Chen G.S. and Yu C.L., The inhibitory effect of UVB irradiation on the expression of $\mathrm{p} 53$ and $\mathrm{Ki}-67$ proteins in arsenic-induced Bowen's disease. J Cutan Pathol 24: 8-13, 1997.

86. Hsieh L.L., Chen H.J., Hsieh J.T., Jee S.H., Chen G.S. and Chen C.J., Arsenic-related Bowen's disease and paraquatrelated skin cancerous lesions show no detectable ras and p53 gene alterations. Cancer Lett 86: 59-65, 1994.

87. Hsu C.H., Yang S.A., Wang J.Y., Yu H.S. and Lin S.R., Mutational spectrum of p53 gene in arsenic-related skin cancers from the blackfoot disease endemic area of Taiwan. Br J Cancer 80: 1080-1086, 1999.

88. Kawara S., Takata M. and Takehara K., High frequency of DNA aneuploidy detected by DNA flow cytometry in Bowen's disease. J Dermatol Sci 21: 23-26, 1999.

89. Yih L.H., Hsueh S.W., Luu W.S., Chiu T.H. and Lee T.C., Arsenite induces prominent mitotic arrest via inhibition of G2 checkpoint activation in CGL-2 cells. Carcinogenesis 26: 53-63, 2005.

90. Yih L.H., Tseng Y.Y., Wu Y.C. and Lee T.C., Induction of centrosome amplification during arsenite-induced mitotic arrest in CGL-2 cells. Cancer Res 66: 2098-2106, 2006.

91. Liao W.T., Chang K.L., Yu C.L., Chen G.S., Chang L.W. and $\mathrm{Yu}$ H.S., Arsenic induces human keratinocyte apoptosis by the FAS/FAS ligand pathway, which correlates with alterations in nuclear factor-kappa B and activator protein-1 activity. J Invest Dermatol 122: 125-129, 2004.

92. Liu Z.G., Hsu H., Goeddel D.V. and Karin M., Dissection of TNF receptor 1 effector functions: JNK activation is not linked to apoptosis while NF-kappaB activation prevents cell death. Cell 87: 565-576, 1996.

93. Faris M., Kokot N., Latinis K., Kasibhatla S., Green D.R., Koretzky G.A. and Nel A., The c-Jun N-terminal kinase cascade plays a role in stress-induced apoptosis in Jurkat cells by up-regulating Fas ligand expression. J Immunol 160: 134-144, 1998.

94. Zagariya A., Mungre S., Lovis R., Birrer M., Ness S., Thimmapaya B. and Pope R., Tumor necrosis factor alpha gene regulation: enhancement of C/EBPbeta-induced activation by c-Jun. Mol Cell Biol 18: 2815-2824, 1998.

95. Kolbus A., Herr I., Schreiber M., Debatin K.M., Wagner E.F. and Angel P., c-Jun-dependent CD95-L expression is a rate-limiting step in the induction of apoptosis by alkylating agents. Mol Cell Biol 20: 575-582, 2000.

96. Okui T. and Fujiwara Y., Inhibition of human excision DNA repair by inorganic arsenic and the co-mutagenic effect in V79 Chinese hamster cells. Mutat Res 172: 69-76, 1986.

97. Lee T.C., Huang R.Y. and Jan K.Y., Sodium arsenite enhances the cytotoxicity, clastogenicity, and 6-thioguanine-resistant mutagenicity of ultraviolet light in Chinese hamster ovary cells. Mutat Res 148: 83-89, 1985.

98. Ziegler A., Jonason A.S., Leffell D.J., Simon J.A., Sharma H.W., Kimmelman J., Remington L., Jacks T. and Brash D.E., Sunburn and p53 in the onset of skin cancer. Nature 372: 773-776, 1994.

99. Gniadecki R., Hansen M. and Wulf H.C., Two pathways for induction of apoptosis by ultraviolet radiation in cultured human keratinocytes. J Invest Dermatol 109: 163-169, 1997.

100. Finucane D.M., Bossy-Wetzel E., Waterhouse N.J., Cotter T.G. and Green D.R., Bax-induced caspase activation and apoptosis via cytochrome c release from mitochondria is inhibitable by Bcl-xL. J Biol Chem 274: 2225-2233, 1999.

101. Sitailo L.A., Tibudan S.S. and Denning M.F., Activation of caspase-9 is required for UV-induced apoptosis of human keratinocytes. J Biol Chem 277: 19346-19352, 2002.

102. Yu H.S., Chang K.L., Yu C.L., Wu C.S., Chen G.S. and Ho J.C., Defective IL-2 receptor expression in lymphocytes of patients with arsenic-induced Bowen's disease. Arch Dermatol Res 290: 681-687, 1998.

103. Soto-Pena G.A., Luna A.L., Acosta-Saavedra L., Conde P., Lopez-Carrillo L., Cebrian M.E., Bastida M., Calderon-Aranda E.S. and Vega L., Assessment of lymphocyte subpopulations and cytokine secretion in children exposed to arsenic. Faseb J 20: 779-781, 2006

104. Wu M.M., Chiou H.Y., Ho I.C., Chen C.J. and Lee T.C., Gene expression of inflammatory molecules in circulating lymphocytes from arsenic-exposed human subjects. Environ Health Perspect 111: 1429-1438, 2003.

105. Yu H.S., Liao W.T., Chang K.L., Yu C.L. and Chen G.S., Arsenic induces tumor necrosis factor alpha release and tumor necrosis factor receptor 1 signaling in $\mathrm{T}$ helper cell apoptosis. J Invest Dermatol 119: 812-819, 2002.

106. Yu H.S., Chen G.S., Sheu H.M., Kao J.S., Chang K.L. and $\mathrm{Yu}$ C.L., Alterations of skin-associated lymphoid tissue in the carcinogenesis of arsenical skin cancer. Proc Natl Sci Counc Repub China B 16: 17-22, 1992.

107. Griffith T.S., Brunner T., Fletcher S.M., Green D.R. and Ferguson T.A., Fas ligand-induced apoptosis as a mechanism of immune privilege. Science 270: 1189-1192, 1995.

108. Murphy G.F., Krusinski P.A., Myzak L.A. and Ershler W.B., Local immune response in basal cell carcinoma: characterization by transmission electron microscopy and monoclonal anti-T6 antibody. J Am Acad Dermatol 8: 477-485, 1983

109. Woods G.M., Malley R.C. and Muller H.K., The skin immune system and the challenge of tumour immunosurveillance. Eur J Dermatol 15: 63-69, 2005.

110. Xiang J., Huang H. and Liu Y., A new dynamic model of $\mathrm{CD} 8+\mathrm{T}$ effector cell responses via CD4 $+\mathrm{T}$ helperantigen-presenting cells. J Immunol 174: 7497-7505, 2005. 